\title{
Who Do I Serve?
}

\section{LISA SLATER}

When I arrived in Aurukun, it was the heat that struck me first, knocking the city pace from my body, replacing it with a languor familiar to my childhood, although heavier, more northern. Fieldwork brings with it its own delights and anxieties. It is where I feel most competent and incompetent, where I am most indebted and thankful for the generosity and kindness of strangers. I love the way 'no-where' places quickly become somewhere and something to me. Then there are the bodily visitations: a much younger self haunts my body. At times my adult self abandons me, leaving me nothing but an awkward adolescent: clumsy, sweaty, too much body, too white, too urban, too disconnected or unable to interpret the social rules. Flailing about, unmoored from the sociocultural system that I take for granted, and take comfort from-from which I draw sustenance. Misusing Deborah Bird Rose, I'm tempted to say I'm separated from my nourishing terrain. ${ }^{1}$ Indeed it can feel like the nation (not the country) slipped out from under my feet.

A few years ago I was recalling fieldwork anxieties to a colleague. His response was to ask, 'who do you serve?' The question threw me: I wanted to say, 'No one, I'm Australian'. A simple provocation and I become a wild colonial girl. We had attended a conference in Delhi together and it got him reminiscing about his time as a student in India: he spent a few years studying and travelling, accumulating friends, stories, bits and pieces of learning and love and devotion to the country. From memory, the 
conversation took place after we'd returned to Melbourne. We were having one of those nurturing collegial conversations: someone keeping me company as I gently worried away at the ethical conundrums of cultural research. He told me that from his long, indolent time spent meandering around India it is the question from a student friend that returned to him most readily, keeping him in check. His friend asked matter-a-factly, 'who do you serve?' It was intended as a straightforward question, assumed to have a ready answer: not designed to illicit consternation, anger and certainly not existential angst. He couldn't answer. But he said now he regularly reflects upon it. The answer had become his navigational star.

Before we parted, he asked again, expecting an answer. I mumbled something about the research project, situated within the larger context of my life. It seemed to me he was suggesting that one should be at the service of the question. If so, my response was feeble. You see, I was in the early stages of a new research project-an Australian Research Council Linkage-on which I was the research fellow, examining the impact of Indigenous festivals on youth and community wellbeing. I hadn't yet got my footing. At the time, I was working across seven sites (albeit with different intensities), talking to school leaders, teachers, mums and dads, artists, festival directors and stakeholders, young people, Elders, bureaucrats, local government, community and non-government organisations, service providers, organisations and lots of people who had been trying to make changes for a long time. There were a lot of interested parties. Many people were generous with their time and attention, and shared a little of themselves: their passions, convictions, reflections, knowledge, memories, joy, pain and longing. It is a humbling experience when a stranger gives one's research time and attention; such a loving gesture.

My friend's pointed question was an ethical and existential one. Who am I ethically obliged to? Well it goes without saying the university and the research project and partner, I am beholden to the people and other things like organisations, the human and non-human, histories and so on that inform the project. And independent scholarship, the field, job satisfaction, everyday pleasures, me and those with whom I share my life. But how am I obliged to all of this? I was in need of a compass.

The purpose of research questions are of course navigational, even if you find them faulty and they are thrown out and replaced. But this is not the point. The 
ethics of research asks so much more. And I feel it is not given its due. Because it is often an encounter: it pokes and prods and is gone, shape shifting, before one's got its proper measure.

Daily I was struck by the importance of creating a space that is not only physical but also mental and emotional, a space where one can define and make claims for oneself in order to offer oneself more boldly to the world of everyday experience. ${ }^{2}$

How does one create space in such estranging places, to offer oneself more boldly? Day by day, I grew to understand how you need a solid subjective standpoint (or node) in order to move productively out to the larger world (or network) of others [these estranging places]. The more solid your grounding, the more nimble you can be with the possibilities when [you] encounter someone else. The more robust the node, the more resilient the entire network. ${ }^{3}$

When I first pondered the question (fair to say, best not done while driving), I used to feel I served too many masters. But my colleagues at the postgraduate and early career researcher rural cultural studies workshops, and writers such as Ross Gibson, cause me to think it anew. Reflecting upon it more recently, I began to see it as a many-armed god. But if so, what is the body or spirit of the god? My fieldwork in Aurukun, West Cape York, got me thinking about spirit. What does the word spirit even mean to me? I had thought my equivalent-'same but different', one of my favourite local terms-was the ethical imagination. But now I'm not so sure-spirit's got more power. It's magic: a creative force. Shouldn't my work animate this spirit?

Who do I serve? I proffer no answer. Rather it nips at my heels. Like magic the answer remains elusive yet appears out of what appears like nothing but is everything. It never settles because once it does the ethics too can easily disappear. The question is the ethics I am enamoured with. The question is proffered again and again in the flash of recognition from a stranger-what is it you do? It repeatedly steps out of the shadows, raises an eyebrow, daring me and reminding me-at each appearance-of the ethics of uncertainty. 
Lisa Slater is a Research Associate at the Hawke Research Institute, University of South Australia. This article is an outcome of her previous project undertaken at RMIT (an ARC Linkage, partner organisation Telstra Foundation), which examined the impact of Indigenous cultural festivals on youth and community wellbeing. Her research seeks to understand and define the processes of neo-colonialism, contemporary Indigenous identity formation and settler-colonial belonging with a particular focus on the role of cultural production-especially Indigenous festivals-as sites for the expression of Indigenous sovereignty and ethical intercultural engagement.

\section{-NOTES}

1 Deborah Bird Rose, Nourishing Terrains: Australian Aboriginal Views of Landscape and Wilderness, Australian Heritage Commission, Canberra, 1996.

2 Ross Gibson, 'Intimacy', from this collection, Cultural Studies Review, vol. 16, no. 1, March 2010.

3 Gibson. 